RESEARCH ARTICLE

\title{
BEYOND EQUAL LIBERTY: RELIGION AS A DISTINCT HUMAN GOOD AND THE IMPLICATIONS FOR RELIGIOUS FREEDOM
}

\author{
MELISSA MOSCHELLA
}

Assistant Professor of Philosophy, The Catholic University of America

\begin{abstract}
In this essay I argue that religion, understood as harmony with the transcendent source of existence and meaning, is a good that practical reason grasps as an objective, distinct, and important aspect of human well-being, one that reasonably takes pride of place among the various aspects of a good human life due to its architectonic role in structuring and adding a transcendent meaning to all of the other goods that we pursue. On the basis of this view of religion, I suggest that religious belief and practice deserve special protection in law, above and beyond mere preferences and even other conscientious commitments. I develop this view through a dialectical engagement with Ronald Dworkin, Brian Barry, and Christopher Eisgruber and Lawrence Sager.
\end{abstract}

KEYWORDS: religious freedom, natural law, conscience, common good

Is religion a category of human activity that should be given special weight or that warrants special treatment in society? Or, to respect religion legally and politically, is it sufficient to treat it on a par with the many other pursuits that people consider meaningful and important in their lives? In this article I hope to shed light on these difficult and timely questions by (I) defending the ethical claim that practical reason grasps religion as a distinct and important aspect of human well-being, one that reasonably takes pride of place among the various aspects of a good human life due to its architectonic role in structuring and adding a transcendent meaning to all of the other goods that we pursue; (2) defending the political philosophical claim that the goal of political societythat is, the common good-is to establish and maintain the set of conditions that best fosters the pursuit and achievement of genuine human well-being by all of the society's members both as individuals and groups; and $(3)$ arguing that given the first two claims, justice requires giving religion special treatment in law that goes beyond equal protection, beyond what Christopher Eisgruber and Lawrence Sager refer to as "equal liberty" in their book Religious Freedom and the Constitution. ${ }^{\text {I }}$

I They explain the main components of their view as follows:

The model, which we call "Equal Liberty," has three distinct components. First, it insists in the name of equality that no members of our political community ought to be devalued on account of the spiritual foundations of their important commitments and projects. Religious faith receives special constitutional solicitude in this respect, but only because of its vulnerability to hostility and neglect. Second, and again in the name of equality, Equal Liberty insists that aside from this deep and important concern with discrimination, we have no 
I explain my understanding of religion as a distinct human good, and briefly discuss the practical implications of my view, through an analysis of several cases, including United States $v$. Seeger, ${ }^{2}$ Welsh v. United States, ${ }^{3}$ and Employment Division v. Smith. ${ }^{4}$

A few preliminaries are in order. First, I should emphasize that my argument is not about constitutional or statutory interpretation, but rather I propose broad principles for determining what justice requires from a moral perspective, with regard to respect for and accommodation of belief and practice on the part of the state. My discussion of actual cases is intended only to illustrate how those principles might apply, not to take a position regarding how any particular case should have been decided as a matter of positive law. In other words, my claims bear on what the law should be, rather than what the law currently is. Second, it is important to note that I approach the question of what justice requires from the so-called new natural law 5 perspective, the presuppositions of which have been explained and defended elsewhere. ${ }^{6}$ My aim here is to clarify and develop this natural law account with regard to the issue of religious liberty and to defend it against the opposing accounts of liberal theorists such as Eisgruber and Sager, Ronald Dworkin, Micah Schwartzman, and Brian Barry.

\section{RELIGION AS A DISTINCT AND ARCHITECTONIC HUMAN GOOD}

Political and constitutional theorists who deny that religion deserves any special treatment in law fail to recognize religion as a distinct human good that practical reason can grasp as such even in the absence of supernatural revelation. Before moving on to examine these theorists' views, I first need to explain my understanding of "practical reason," which is central to my overall account.7 I presume here, in line with natural law theory and the Aristotelian-Thomistic tradition of moral and political thought more broadly, that practical reason is not, as Hume would have it, a "slave of the passions" that merely figures out the best means to achieve ends determined by subrational desire. ${ }^{8}$ Of course, reason can be (and often is) deflected by subrational desire and coopted into its service. Yet human flourishing, the goal of the moral life, requires acting fully reasonably, avoiding such cooption. On the natural law view, moral obligation is not something extrinsic to reason, but flows directly from the requirements of practical reasonableness. For reason can itself grasp certain intelligible (as opposed to sense-perceptible) goods as ends, as intrinsically and not merely instrumentally worthy of pursuit, goods that are constitutive of our flourishing as human

constitutional reason to treat religion as deserving special benefits or as subject to special disabilities. Finally, Equal Liberty insists on a broad understanding of constitutional liberty generally.

Christopher L. Eisgruber and Lawrence G. Sager, Religious Freedom and the Constitution (Cambridge, MA: Harvard University Press, 2007), 52 (emphasis added).

2 United States v. Seeger, 380 U.S. I63 (1965).

3 Welsh v. United States, 398 U.S. 333 (1970).

4 Employment Division v. Smith, 494 U.S. 872 (1990).

5 The adequacy of this label is questionable, but I refer to it as such because it is the simplest way of clarifying the particular strand of natural law thinking upon which I will be drawing. Having done so, however, for the remainder of the article I refer simply to natural law.

6 John Finnis, Natural Law and Natural Rights, 2nd ed. (New York: Oxford University Press, 20Ir).

7 For a full account of practical reason and the basic goods according to the new natural law theory, see ibid., especially chapters $3-5$ and the related clarifications in Finnis's postscript, $442-57$.

8 David Hume, A Treatise of Human Nature (1888; repr. Oxford: Clarendon Press, 1967), 4I 5 (book 2, part 3, section 3). 
beings. Many natural law theorists refer to these intelligible goods as "basic goods," or basic and constitutive aspects of human well-being, and claim that practical reasoning presupposes a grasp of the basic goods as "to be pursued" (and their opposites as "to be avoided") in the same way that theoretical reasoning presupposes a grasp of the principle of non-contradiction-the principle that a thing cannot both be and not be at the same time and in the same respect. Among the basic goods are life, health, knowledge, friendship, and-crucially for my argument-religion and authenticity, as defined below. Given that the choiceworthiness of each of the basic goods is grasped as a first principle, the practical truth that a basic good is to be pursued, like the theoretical truth of the principle of noncontradiction, cannot be demonstrated strictly speaking (since any demonstration would have to presuppose it), but it can be argued for dialectically-for instance, by showing how its truth is implied by other beliefs of whose truth we are certain or by showing that denying it leads to a theoretical or practical contradiction.

\section{Religion as a Distinct Human Good}

Prominent among the theorists who deny that religion is a distinct basic good that practical reason can and usually does grasp as such are Eisgruber and Sager, Dworkin, Schwartzman, and Barry, as well as Brian Leiter. Eisgruber and Sager treat religion as just one among many "human projects and commitments" and make no reference to the actual goodness of those commitments or to the actual truth of the beliefs that underlie them. ${ }^{9}$ Leiter likewise argues that there is nothing about religion as such that makes it distinctive and therefore deserving of special protection. ${ }^{\text {Io }}$ Dworkin considers religious convictions as one among many types of convictions that, in the words of the Planned Parenthood v. Casey decision, "define the attributes of personhood,"II and that are on a par with convictions about things like whether or not to have an abortion or engage in sodomy. ${ }^{\mathrm{I} 2}$ Schwartzman believes that secular doctrines that address ultimate questions and are sufficiently comprehensive in scope "cannot be distinguished on normative, epistemic, or psychological grounds from their religious counterparts." ${ }^{13}$

Looking at the issue from the perspective of what justice requires in general rather than from a specifically legal perspective, Barry similarly argues that religion deserves no privileged treatment. Rather, on Barry's account justice simply requires equal opportunity, understood as the situation in which everyone has an equal choice set. Neither the fact that some "will make different choices from these identical choice sets, depending on their preferences for outcomes and their beliefs about the relation of actions to the satisfaction of their preferences," nor the fact that for some these preferences and beliefs will be the result of religious, cultural, or moral commitments, is in any way relevant to claims of justice. ${ }^{14}$ As for Dworkin ${ }^{15}$ and others, for Barry religion is one belief

9 Eisgruber and Sager, Religious Freedom, 24.

Io Brian Leiter, Why Tolerate Religion? (Princeton: Princeton University Press, 20I2).

I I Planned Parenthood of Southeastern Pennsylvania v. Casey, 505 U.S. 833 (I992).

I2 Ronald Dworkin, Is Democracy Possible Here? Principles for a New Political Debate (Princeton: Princeton University Press, 2006), 72. See also Ronald Dworkin, Religion without God (Cambridge, MA: Harvard University Press, 2013), I07, I I4, II9.

I3 Micah Schwartzman, "What If Religion Is Not Special?” University of Chicago Law Review 79, no. 4 (2012): I $35 \mathrm{I}-427$, at $\mathrm{I} 42 \mathrm{I}$.

I4 Brian Barry, Culture and Equality: An Egalitarian Critique of Multiculturalism (Cambridge, MA: Harvard University Press, 200I), 32.

I 5 Here I am referring to the understanding of religion implicit in Dworkin, Is Democracy Possible Here? Later I engage Dworkin's more recent discussion of religion in Religion without God. 
or preference among many, and its importance in any given life depends entirely on what an individual happens to find satisfying - some might have a taste for expensive caviar, others for sexual activity with minors (both are Barry's examples), others for going to church. While, as in the case of pedophilia, justice allows and at times requires placing limits on the pursuit of one's preferences insofar as doing so violates the important interests of others, in every other respect justice requires treating all preferences equally.

This view of what justice requires - which is inseparable from a view about what law should protect or promote-rests on one or both of the following assumptions: (I) religion's value is subjective, relative to the particular tastes, preferences, and values of each individual; (2) religion's value, even if objective, is not essentially distinct from or more important than the value of nonreligious ethical or philosophical beliefs. In line with these assumptions, Barry, Dworkin, and other liberal theorists deny that religion deserves special protection in law, and hold, either implicitly or explicitly, that the overriding value the state should protect is autonomy, the freedom to choose and pursue one's own values and commitments in life, whatever they might be, as long as this does not involve significant nonconsensual harm to others. ${ }^{\mathrm{I}}{ }^{6}$ Yet if reason grasps religion as something objectively and distinctively valuable for human beings, and not only as one among many objective goods that contribute to human fulfillment, but as a good that plays an architectonic (that is, governing and structuring) role in the good life, then justice - and by extension, law-requires giving it special treatment in accordance with its special role in human life.

Before defending the claim that religion is indeed a distinct aspect of human well-being, let me offer a preliminary sketch of what I mean by "religion," a fuller account of which will emerge in dialogue with the contrasting views of other theorists. When I speak of religion as a basic human good, one among many intrinsically choiceworthy goods that perfect us as human beings-goods like health, knowledge, and friendship-I refer to the good of knowing the truth with regard to ultimate questions of existence and meaning, and of being in harmony with the transcendent source of existence and meaning (usually referred to as God). ${ }^{17}$

The existence of such a transcendent source of existence and meaning is something accessible to human reason, which can grasp the need for a noncontingent cause (that is, a necessary being) as

I6 William Galston, Martha Nussbaum, and Paul Bou-Habib offer similar accounts of religion and of the grounds of religious liberty. While differing in many ways among each other and from Barry, Dworkin, Leiter, Schwartzman, and Eisgruber and Sager, all of these authors share in common the view that ultimately religion's value depends on subjective preferences, and all deny that religion is something objectively and distinctively valuable in itself. Galston, for instance, speaks of religious liberty under the umbrella of "expressive liberty," which he defends on the grounds that, "for most of us, impediments to acting on our deepest beliefs are experienced as sources of deprivation and unhappiness, resentment and anger." William A. Galston, Liberal Pluralism: The Implications of Value Pluralism for Political Theory and Practice (Cambridge: Cambridge University Press, 2002), 29. Bou-Habib, likewise, speaks of a "right to integrity," understood as a right to fulfill one's perceived duties, based on the claim that a rational, well-informed person would prefer a life of integrity to a life without integrity. Paul Bou-Habib, "A Theory of Religious Accommodation," Journal of Applied Philosophy 23, no. I (2006): I09-26, at II7. Nussbaum claims that respecting people as equals requires respecting their conscientious commitments except when those commitments involve actions that threaten the rights of others. Martha C. Nussbaum, Liberty of Conscience: In Defense of America's Tradition of Religious Equality (New York: Basic Books, 2008).

I7 Here I am following the characterization of the good of religion in Finnis's Natural Law and Natural Rights, 90, and the development of that characterization in Joseph Boyle's "The Place of Religion in the Practical Reasoning of Individuals and Groups," American Journal of Jurisprudence 43, no. I (I998): I-24. 
the source of the contingent universe in which we live and of which we form a part. ${ }^{\mathrm{I}}$ Philosophers from Plato up to the present day have offered a variety of sophisticated arguments along these lines for the existence of such a being. While debates about the success of these arguments is ongoing, one need not be a philosopher or even be able to articulate a rational argument for God's existence to have a firm and reasonable conviction of this metaphysical truth, just as one need not be able to give a sophisticated rational account of the wrongness of killing innocent human beings (another topic of ongoing philosophical debate) to have a firm and reasonable conviction of that moral truth. Attesting to the fact that knowledge of some transcendent source of existence and meaning is accessible to human reason is the pervasiveness of the belief in a higher power throughout history and across a variety of cultures. Although this point applies most strongly to Western cultures, ${ }^{19}$ with which I have the most familiarity, my understanding is that most of the more popular forms of Buddhism, Hinduism, and other Eastern religions include some conception of the divine, or at least hold that there is a transcendent order (an order not dependent on human will) to which one must conform. ${ }^{2 \circ}$ Genuine atheism (understood strongly as a complete denial of the divine and of a transcendent order) - as opposed to mere rejection of institutional religion or a particular conception of the divine-is relatively rare in human history until the modern era. Although in the developed world atheism and agnosticism are becoming increasingly common, many of those who consider themselves atheists or agnostics would actually not be, on my definition of God as the transcendent source of existence and meaning. Even Dworkin acknowledges that "many millions of people who count themselves as atheists ... nevertheless believe in a 'force' in the universe 'greater than we are." ${ }_{21}$

Yet even if an explicit belief in God as the transcendent source of meaning and existence is not a universal cross-cultural phenomenon, religiosity more generally is, and this pervasiveness of religion is more relevant for the sake of my current argument that the importance of religion as a distinct human good is readily (if often imperfectly) grasped by practical reason. Indeed, a central aspect of the human good of religion is precisely the recognition that questions about the ultimate origin and meaning of one's life and of the cosmos are questions regarding which it is "peculiarly important to have thought reasonably and (where possible) correctly ... whatever the answer to those questions turns out to be, and even if the answers have to be agnostic or negative." ${ }^{22}$ The importance of these religious questions, and of ordering one's life in accordance with one's answers to them should one's quest reveal the existence of a God, are grasped by practical reason as first principles without the need (or possibility) of a rational demonstration in much the same way as practical reason grasps the values of friendship and sociability (living in harmony with other human beings), of being in good health, of attaining knowledge, of developing one's talents and skills, and of achieving an inner harmony among the reasoning and desiring aspects of oneself. While only supernatural revelation (a direct communication from God to us such as that which many people believe is recorded in the Bible) could enable us to know that God actually cares about whether or not we live in harmony with him, no such revelation is required in order to

I 8 For a more fully developed argument on this point, see John Finnis, "Religion and State: Some Main Issues and Sources," American Journal of Jurisprudence 51, no. I (2006): 107-30; Finnis, "Does Free Exercise of Religion Deserve Constitutional Mention?” American Journal of Jurisprudence 54, no. I (2009): 4I-66.

I9 I thank an anonymous reviewer for pointing this out.

20 There is controversy regarding whether or not Buddhism can be considered theistic in any meaningful sense. For a sense of the debate, see, for instance, Robert E. Florida, "Theism and Atheism in the Work of W. C. Smith: A Buddhist Case Study," Buddhist-Christian Studies Io (1990): 255-62.

2 I Dworkin, Religion without God, 2.

22 Finnis, Natural Law and Natural Rights, 89. 
grasp, on our part, the value of knowing the truth about God (including the truth about whether or not God exists), and of being in harmony with God if there is one. Ancient philosophers such as Socrates, Plato, and Aristotle, who predate Christianity by hundreds of years and were not (as far as we know) aware of the Jewish scriptures, nonetheless clearly recognize this good, and they recognize it as one of particular importance. In the Apology, Socrates portrays his overriding mission in life not simply as a quest to discover and spread the truth, but as a quest undertaken in obedience to what he perceives to be a divine calling, to be faithful to which he is willing to sacrifice life itself. Further, while Aristotle thinks that, strictly speaking, there can be no friendship between a human being and God due to the great inequality between them, ${ }^{23}$ he assumes that becoming "dear to the gods" is itself a reason for action (and one that is architectonic with respect to other goods) when he argues for the excellence of the contemplative life on the grounds that the wise man "would be most dear to the gods" and, for that reason, "the most happy of men." ${ }^{24}$ That as humans we grasp the self-evident choiceworthiness of knowing the truth about God and ordering or lives in line with that truth makes sense of the fact that throughout human history human beings have organized their lives not only as individuals but as whole communities in a way that is governed by the good of religion. As indicated in the root word cult, historically culture has centered primarily on religion, around maintaining and fostering the beliefs and practices that establish the community and its members in a right relationship with the transcendent source of meaning and existence.

It is also important to note that, as with other human goods, one can at least partially grasp the value of religion even if one has an objectively defective understanding of it. For example, one can grasp the value of friendship (albeit imperfectly) even if one has a somewhat impoverished conception or experience of friendship as largely based on utility or pleasure, rather than as a mutual and mutually recognized commitment to the well-being of another. ${ }^{25}$ Likewise, one can see the point and particular importance of the religious quest even if one (erroneously, in my view) comes to the conclusion that there is no transcendent source of existence and meaning.

Authors like Barry, Schwartzman, Dworkin, and Eisgruber and Sager may grant that many people consider religion as I define it to be a distinct and architectonic human good, but they would be likely to question the claim that in fact religion (as I understand it) is not reducible to or interchangeable with other goods, as well as the claim that, by its very nature, religion is architectonic-that it is a good that governs and structures one's pursuit of all of the other basic goods. Dworkin, ${ }^{26}$ for instance, might argue that what really matters is the freedom to choose one's values for oneself, and to have one's freedom of choice respected by the political community insofar as is compatible with equal respect for the freedom of others. It is not really the specific freedom to exercise religion that matters, Dworkin might say, but rather the freedom to act on one's convictions, whatever those might be.

But is there really anything intrinsically valuable about acting on one's convictions, whatever those might be? If a young woman, despite already being a healthy weight, is convinced that she will only be attractive if she loses fifty pounds, and she goes about pursuing that goal by practically starving herself, there is clearly no genuine value in her actions despite the fact that they are an exercise of her freedom of choice. If a forty-year-old man is convinced that he will find fulfillment only through sexually intimate relationships with young boys, there is no value in acting on that conviction.

23 Aristotle, Nicomachean Ethics, II 59 a7.

24 Ibid., II79азо.

25 Ibid., book 8.

26 Again, here I attempt to characterize Dworkin's position on the matter as expressed in Is Democracy Possible Here? Below I discuss his views as expressed in Religion without God, which, I argue, are only superficially different. 
Further, the lack of value in each course of action is not merely due to the fact that the first results in serious harm to one's health while the second results in nonconsensual harm to others. In order to be able to play the role of an anorexic woman in a movie, an actress might try to bring herself down to an anorexic weight, and insofar as this action is part and parcel of the pursuit of professional excellence or the education of the public about the dangers of anorexia, this action would be valuable. Likewise there are actions that may involve harm to others-such as using physical force against an attacker to defend one's children - that we would consider valuable.

The difference between the first pair of cases and the second pair of cases is that in the first two cases no genuine good was being pursued; in those cases the person was acting based not on reason, but on subrational desire. In the first case, the woman's actions could be explained by a subrational desire, perhaps induced by media and advertising, to conform to a completely unreasonable and false ideal of feminine attractiveness. In the second case, the man's actions involved acting on a subrational desire to achieve sexual gratification in isolation from any intelligible human good. In the second set of cases, by contrast, the individuals were acting in pursuit of intelligible goods - performative excellence, the diffusion of knowledge, the life and health of other human beings-goods that practical reason grasps as intrinsically choiceworthy, rather than in pursuit of the mere satisfaction of desire. Acting on one's own convictions (if convictions are understood to include beliefs based on subrational desire) is therefore clearly not the broader value within which religion is subsumed as Dworkin claims, since it is, as such, not a value at all.

In Religion without God, Dworkin appears to accord religion more importance and distinctiveness than in his prior work, but he does this only by watering down the definition of religion to the point at which it is practically indistinguishable from the freedom to act on one's convictions, whatever those might be. ${ }^{27}$ Dworkin describes the religious attitude as follows:

The religious attitude accepts the full, independent reality of value. It accepts the objective truth of two central judgments about value. The first holds that human life has objective meaning or importance. Each person has an innate and inescapable responsibility to try to make his life a successful one: that means living well, accepting ethical responsibilities to oneself as well as moral responsibilities to others, not just if we happen to think this important but because it is in itself important whether we think so or not. The second holds that what we call "nature" - the universe as a whole and in all its parts - is not just a matter of fact but is itself sublime: something of intrinsic value and wonder. ${ }^{28}$

Dworkin sums up the religious attitude as marked by two essential convictions: "life's intrinsic meaning and nature's intrinsic beauty." 29

At first glance, this characterization of religion seems to have much in common with the natural law approach. But the superficial similarities mask crucial differences. First of all, Dworkin's remarks about accepting ethical responsibilities, which are important whether or not we think

27 I focus here on Dworkin's definition of religion because it is more developed than the definitions of Barry, Schwartzman, and Eisgruber and Sager but not so different from theirs as to make my critique of Dworkin inapplicable to the others. Schwartzman briefly defines religion as addressing ultimate questions and being comprehensive in scope, a definition that be believes can be equally applied to secular doctrines. Schwartzman, "What If Religion Is Not Special?," I4I 8-I9. Eisgruber and Sager similarly present the following four characteristics as common to most religions: (I) comprehensiveness, (2) cohesiveness, in the sense of distinguishing insiders from outsiders, (3) having some ritual aspect, and (4) momentousness, in terms of the importance religious questions have for the believer. Eisgruber and Sager, Religious Freedom and the Constitution, 125-26.

28 Dworkin, Religion without God, ro.

29 Ibid., II. 
they are, have to be read in light of his understanding of the independent reality of value. Dworkin's view regarding the independent reality of value marks a crucial distinction from the natural law approach. The natural law theory within which I am working recognizes the epistemic independence of value, but not its metaphysical independence. In other words, it recognizes that our knowledge of values is not epistemically derived from any facts about the world or metaphysical beliefs. ${ }^{\circ}$ Yet-and this marks a fundamental divergence from Dworkin's view-on a natural law account the existence of values is metaphysically dependent on the order of the universe, and therefore ultimately on God as the author of that order. In answer to the famous question posed in Dostoyevsky's The Brothers Karamazov-whether, "if there is no God, everything is permitted" - the answer from a natural law perspective would be both yes and no. Yes, because if there is no God, then there is no natural order; but this does not mean much, because, by the same token, if there is no God, there is nothing at all. And no, because, without knowledge of the existence of God or without taking God's existence as a starting point in one's reasoning, practical reason is capable of grasping the existence of objective values - namely, the basic human goods mentioned earlier-and of discovering second-order moral norms that govern our pursuit of those values, norms like the prohibition on intentionally damaging or destroying a person's well-being in any of its basic dimensions. Dworkin, by contrast, denies not only the epistemic dependence of values on belief in God, but also the metaphysical dependence of the moral order on God. This is, I believe, a key difference between the two views that goes hand in hand with their superficially similar but in fact importantly distinct understandings of religion. ${ }^{3}{ }^{\text {I }}$

A second, related difference between the natural law view of religion and Dworkin's view of religion is that Dworkin's view lacks any essential reference to the transcendent in the fullest sense. ${ }^{22}$ The transcendent seems to be replaced or at least watered down in Dworkin's account with references to the mystery and sublimity of nature. Of course, nature has a certain transcendence in that it goes beyond the human, but not the robust transcendence of a being or force outside and beyond the realm of nature as a whole. By contrast, on a natural law conception the importance of thinking seriously and well about questions regarding the ultimate origins of existence and meaning consists to a large extent in the recognition that, "if there is a transcendent origin of the universal order-of-things and of human freedom and reason, then one's life and actions are in fundamental

30 Finnis, Natural Law and Natural Rights, 34, chapter I3. See also John Finnis, Fundamentals of Ethics (Washington, DC: Georgetown University Press, 1983), 21; John Finnis, Collected Essays, vol. I, Reason in Action (Oxford: Oxford University Press, 20II), 5.

3 I In order to understand, more generally, the fundamental differences between Dworkin's theory of value and the theory of value defended by natural law theorists, it is worth noting that Dworkin's references to "intrinsic meaning” or "objective value" are not at all synonymous with natural law theorists' references to "basic goods" or "intrinsic values." For natural law theorists, the claim that goods like life, knowledge, friendship, and religion are intrinsically valuable means that they are, in themselves, reasons for action. To grasp something as a basic good, on the natural law account, is to grasp it as something that is to be pursued, protected, and promoted. Dworkin, however, seems to refer to something as intrinsically valuable to indicate only that it is nonfungible for or incommensurable with other values, not that it is a reason for action in itself. This is why in Life's Dominion Dworkin can claim that all human life is intrinsically valuable and at the same time claim that is not necessarily unreasonable (or wrong) to engage in intentional killing of a human being in the womb or of a terminally ill human being who requests it. Ronald Dworkin, Life's Dominion: An Argument about Abortion, Euthanasia and Individual Freedom (New York: Vintage Books, 1993). On the natural law view, by contrast, the claim that something is a basic good implies that it is always unreasonable (and therefore wrong) intentionally to damage or destroy that good, in oneself or in another.

32 This is also a crucial difference between the natural law account of religion and the views of Schwartzman and Eisgruber and Sager. See note 27. 
disorder if they are not brought, as best one can, into some sort of harmony with whatever can be known or surmised about that transcendent other and its lasting order." ${ }_{33}$ In speaking about the mystery and sublimity of nature, Dworkin seems to accord this "lasting order" of nature in itself the role that the transcendent cause of that order plays in the natural law account. There is thus a trace of the true good of religion in Dworkin's account, but an extremely weak one. It is no surprise, then, that his account masks the distinctiveness and unique importance of religion in the fullest sense.

Indeed, there is a stark contrast between Dworkin's description of the religious attitude as resting in part on the recognition that "each person has an innate and inescapable responsibility to try to make his life a successful one" and Finnis's rhetorical question, "Does not one's own sense of 'responsibility,' in choosing what one is to be and do, amount to a concern that is not reducible to the concern to live, play, procreate, relate to others, and be intelligent?" ${ }_{4}$ We could add "appreciate the beauty and sublimity of nature" to the list without undermining Finnis's point. What makes religion a distinct human good, on the natural law view, is that it consists in "an irreducibly distinct kind of order" - that is, an order distinct from the order one brings to (I) the pursuit of human goods like life, knowledge, aesthetic experience, and performative excellence through one's reasonable prioritization of them in a coherent plan of life; (2) the order that one brings into human relationships; and (3) the order that one brings to one's own character and activity. Distinct from these orders that we can create in ourselves, our activities, and our social relations (orders that relate to the other basic human goods), religion consists in establishing and maintaining the right order between oneself (and one's choices, activities, and social relations) and the transcendent source of all order. This point is crucial, and it has not been sufficiently emphasized elsewhere. For it is the (at least potential) relationship to the transcendent that is the condition sine qua non of religion's distinctiveness.

This clarification of religion's distinctiveness also helps us to understand more fully the architectonic role that religion plays in the good life. For, as Finnis points out, living in a fully reasonable way requires establishing a rational order within oneself and among one's choices, activities, and social relations. Religion is architectonic because it orders-that is, governs and structures-all of these other orders. In other words, for the person fully aware of the demands of religion, the reasonableness of the order of priorities that one establishes in the pursuit of other goods, the quality of one's character, and the justness of one's social relations, must all be judged and governed with respect to the overarching divinely established order in general, and also with respect to any personal religious vocation that one believes oneself to have received.

By cutting off the transcendent element, Dworkin effectively decapitates (and thus kills) religion understood as a distinct human good, reducing it to a combination of other human values and erasing the basis for its distinctiveness and its architectonic role in the good life. It is therefore not surprising that many of the concrete examples of "religious" questions that Dworkin discusses in Religion without God are the same as the examples given in Is Democracy Possible Here?, indicating that to a great extent Dworkin continues to reduce the value of religion to the value of following one's convictions, whatever those might be. In Religion without God, for instance, Dworkin again quotes Casey's "mystery passage" and refers to sexual freedom and the freedom to have an abortion as matters of religious liberty, just as he does in Is Democracy Possible Here? when offering examples of convictions that are just as important as religious ones. Thus the difference between

33 Finnis, Natural Law and Natural Rights, 89-90. 
the two works seems to be that, instead of claiming that religion lacks special importance because it is on a par with other nonreligious convictions, in the more recent book Dworkin recognizes "religion's" special importance but defines it in such a way as to make it indistinguishable from nonreligious convictions. ${ }^{35}$ While there is a trace of the true good of religion in Dworkin's characterization, from a natural law perspective his view is highly impoverished, just as someone who largely reduces friendship to utility or pleasure has a highly impoverished understanding of the good of friendship, which is useful and pleasant, but consists in much more than utility and pleasure alone.

\section{Religion as Uniquely Architectonic, Pervasive, and Meaning-Giving}

The denial of religion's genuine distinctiveness is closely connected to a failure to recognize its uniquely architectonic, pervasive and meaning-giving role in human life. While there are other values constitutive of human well-being that reason grasps as intrinsically choiceworthy-values like health, knowledge, and friendship - religion is special because it governs and orders the pursuit of all other values, and it does so in a way that practical reasonableness alone (which also governs and orders the pursuit of other values) does not. As Christopher Tollefsen points out, religion is unique because (in its most robust sense) it involves recognizing the existence of a transcendent being who is the source of existence and meaning in general, and thus, personally, the source of my existence and capacities; of the world on which I depend for the continuation of my existence and the development of my capacities; of the goodness of the things that my reason grasps as good; of my ability rationally to grasp their goodness; and of my ability to achieve those things. Given the rationally accessible realization of our radical dependence on the transcendent cause of our existence, it makes sense to see "every endeavor as part of a potentially cooperative relationship with this being. ... One's every action, from this standpoint, will be suffused with both gratitude, for the gift that has been given, attentiveness, to what God is asking of us as regards our participation in the relationship, and profound significance, insofar as everything that we do will either contribute positively or negatively to the building up of that relationship." ${ }_{36}$

As a result, without negating the distinctive choiceworthiness of other goods, religion is a good that is uniquely pervasive insofar as it can govern, and be at stake in, every single choice that we make (even, by contrast with the good of practical reasonableness, choices that are morally underdetermined), and also gives our choices an importance and meaning that they might not otherwise have. We can take care of our health not only because we recognize health as an intrinsic aspect of our well-being but also and at the same time because we believe that maintaining ourselves in good health will enable us to work longer and more effectively in God's service. We can pursue friendship not only for its own sake but also because we believe that we are all God's children and God is pleased when we reach out to one another and care for one another. It is possible, of course, for many goods to supervene upon others in this way: for instance, we can take care of our health

35 This is essentially equivalent to Schwartzman's suggestion that all doctrines, whether secular or religious, should be treated equally in law provided that they are sufficiently important in their subject matter and comprehensive in scope. Schwartzman, "What If Religion Is Not Special?," I 420 , which in turn is essentially the same as Eisgruber and Sager's call for "equal liberty," at least with respect to the question of religious accommodations. By contrast with Eisgruber and Sager, on Establishment Clause issues Schwartzman would equalize the playing field by making it illegitimate for the government to legislate on the basis of religious and comprehensive secular doctrines. Ibid., I422.

36 Christopher Tollefsen, "Conscience, Religion and the State," American Journal of Jurisprudence 54, no. I (2009): 93-I I 5, at 99. See also Boyle, "Place of Religion in the Practical Reasoning of Individuals and Groups." 
or pursue knowledge in order to please our friends. Similarly, the good of practical reasonableness governs, and is at stake in, all choices between right and wrong courses of action (as opposed to choices that are morally underdetermined). But only the good of religion can govern and be implicated in every choice at every time and in every circumstance, and only the good of religion should govern (at least implicitly) every choice at every time and in every circumstance. By contrast with the good of religion, while we may take care of our health in order to please our friends, there is no general sense in which one would be more fully reasonable if one's pursuit of the good of health or of any other good were further ordered to or governed by the good of friendship. In other words, religion is unique in that, for the person who is fully aware of its claims as a human good, full practical reasonableness requires that the good of religion govern and order one's overall plan of life, as well as (at least implicitly) every choice and action. Thus, for instance, a young woman trying to decide on a particular professional path must not only consider her particular tastes, talents, and inclinations along with her particular obligations to other people and the needs of her society, but must rather consider all of those factors in addition to, and as indicators of, the particular vocation that God has in mind for her.

Further, recognizing the architectonic and pervasive role that religion should play in one's life considerably heightens the importance of one's choices and actions. For the person aware of the requirements of religion, lying to a friend not only damages human well-being with regard to the goods of friendship, knowledge, integrity, and authenticity, but also damages one's relationship to God and manifests ingratitude for God's many gifts, not least of which are one's own existence and one's very ability to make free choices. The same is true of any other immoral act. The contrary can be said of morally good acts, which not only promote human well-being in one or more of its basic dimensions but can also improve one's relationship to God and express one's gratitude to him. Further, although the good of practical reasonableness would also be implicated in the above cases, for the religious person, even actions and choices that are morally indifferent or of little importance in themselves - for example, brushing one's teeth or ironing one's clothes - can take on transcendent meaning and value if done out of love for God. As the great Spanish mystic Saint Teresa of Avila famously counseled the nuns of her order, "Know that even when you are in the kitchen, our Lord is moving among the pots and pans." 37 What she meant by this was that if your duties require you to work in the kitchen, then that is where God calls you to be, and conscientiously fulfilling those duties is a way of growing closer to God, expressing your love for him, and ordering your life in accordance with God's will. By contrast, the sorts of convictions that Dworkin and other liberal theorists speak of as constitutive of or on a par with religion lack this pervasive and transcendent governing and meaning-giving character.

Tollefsen's remark, quoted above, about the rational requirement to be attentive to what God may be asking of us as regards our relationship with him, leads me to another important point. Although up to now I have referred only to what might be called "natural religion," religion insofar as it can be understood and pursued according to the light of natural reason alone, the requirement of natural religion that we be attentive to what God is asking of us also includes the imperative to consider seriously the historical claims that have been made regarding God's direct self-revelation to human beings - first through more-or-less veiled communications about himself and the conditions for a right relationship with him that were made, as it is claimed in the Judeo-Christian tradition, to figures like Abraham and Moses and the prophets, and then, as Christians believe, through the definitive revelation given when God took on a human nature in Jesus Christ. Similarly,

37 Teresa of Avila, The Book of Foundations, chapter 5.8. 
Muslims claim that God revealed himself to them through Mohammed, Mormons through Joseph Smith, and so on. Thus, seriously and open-mindedly assessing the claims to truth of the various world religions and acting in accordance with one's assessment is itself a requirement of the good of religion. This is ultimately the reason why coercion in religious matters is such a serious threat to human well-being, insofar as it prevents or makes difficult the serious and open-minded pursuit of truth in religious matters, and also insofar as it hinders individuals from acting in accordance with what they sincerely believe to be God's will for them.

What has been said thus far makes it clear that the understanding of religion underlying the views of theorists like Barry, Dworkin, and Eisgruber and Sager is seriously deficient on several counts. First, they fail to recognize that the choiceworthiness of religion (in the full-bodied sense, not in the emaciated sense in which Dworkin uses it in his recent work) is something that practical reason can grasp, and usually does grasp unless blinded by some subrational factor. Indeed, Dworkin believes (although he himself does not rely on this argument) that the Rawlsian ideal of public reason requires what he calls a "tolerant secular state," a state that is neutral not only among religions but even between religion and irreligion. ${ }^{38}$ This claim implies the view (which I have argued to be false) that the existence of God and the choiceworthiness of being in right relation with God (as distinct from simply following one's convictions more generally) are not accessible to reason. Second, they (especially Barry) ignore the crucial difference between religion, which reason grasps as intrinsically choiceworthy, and the pursuit of subrational tastes and preferences, like a predilection for expensive caviar. Along these same lines, they also fail to distinguish between intrinsic and instrumental goods, as well as between genuine goods and merely apparent goods. Third, they do not consider the uniquely architectonic, pervasive, and meaning-giving role that the good of religion has in the life of someone who is aware of its demands (that is, someone who is fully practically reasonable), a role that can only be accounted for by reference to the distinctive feature of religion as seeking the truth about, and ordering ourselves in relation to, the transcendent source of existence and meaning. Since their arguments against giving religion privileged treatment in law are based on this failure to recognize the true nature and distinctiveness of religion as a constitutive aspect of human well-being that is uniquely architectonic, pervasive, and meaninggiving, those arguments are inherently flawed at their very core.

\section{RELIGION AND THE POLITICAL COMMON GOOD}

Theorists like Barry, Dworkin, and Eisgruber and Sager might respond that the foregoing is irrelevant because, even if the analysis is correct, it is not appropriate for the state to make laws and policies to promote any particular substantive vision of the good life. Rather, they might say, law should strive to maintain a neutral stance, insofar as is possible, toward the various competing conceptions of the good life. Perhaps in one comprehensive conception of the good life (such as that of, say, certain contemporary natural law theorists), religion as natural law theorists understand it plays a distinct and architectonic role; but in other competing comprehensive worldviews (such as a comprehensive liberal or utilitarian conception of the good life) it does not. It would be wrong, so the argument goes, for the state to play favorites in this regard.

38 Dworkin, Is Democracy Possible Here?, 64. 
Dworkin, for instance, argues that laws offend human dignity (which he defines in part as requiring "each of us to take personal responsibility for his ethical convictions" ${ }^{39}$ ), when they are based on a "personally judgmental" justification, that is, when their justification "appeals to or presupposes a theory about what kinds of lives are intrinsically good or bad for the people who lead those lives." 40 Such laws are problematic, he claims, because they "violate dignity by usurping an individual's responsibility for his own ethical values." ${ }_{4 \mathrm{I}}$ Yet no argument is given for this crucial claim, and it does not hold up under scrutiny.

One example that Dworkin gives of a law that would offend dignity in this way is a law prohibiting abortion. How such a law would usurp anyone's responsibility for his own ethical convictions is highly unclear. A distinct human organism begins to exist at sperm-egg fusion-this is simply a matter of scientific fact. Philosophers have differing opinions about what it is that gives a being moral status, and some claim that human embryos or fetuses at least up until a certain stage of development lack moral status and therefore lack a right not to be killed. Supposedly, a law against abortion would usurp one's responsibility to decide this matter for oneself. But what about the question of infanticide? Most of the moral philosophers-including Mary Ann Warren, Michael Tooley, Peter Singer, and Jeff McMahan-who think that abortion is morally permissible because a human fetus lacks the qualities that give a being moral status, argue that infanticide is morally permissible for the same reason. ${ }^{42}$ Are laws against infanticide therefore illegitimate on Dworkin's view as well, for the same reasons as laws against abortion? Likewise, there was a time when many people sincerely believed that African Americans lacked full moral status. Was it illegitimate for the state to take sides on this controversial moral issue by making slavery illegal?

My point here is that laws inevitably promote or disfavor one particular conception of the good life or another. Laws educate; this is an essential part of their function and an important way in which they can serve the common good. ${ }^{43}$ Dworkin is right that the responsibility to form one's ethical convictions is a crucial aspect of human dignity, but to form one's ethical convictions responsibly is not to form them in a vacuum, without any external influence whatsoever. Human beings need to be educated, and their education comes not only from parents and family members and teachers but also from the broader culture and the laws that shape that culture. We are not, of course, determined by these educational influences-reason gives us the ability to think critically about what we have been taught and about the dominant values in our societybut they are important nonetheless. Recognizing the inevitable educational function of law (at least indirectly through the ways in which laws shape behavior and behavior shapes culture) and the impossibility of neutrality among competing conceptions of the good life means that, when it is necessary to legislate on a particular matter that relates to controversial moral questions, we should at least try to base our laws on true moral beliefs rather than false ones. ${ }^{44}$

39 Ibid., 65.

40 Ibid., 70.

4 I Ibid., 7 I.

42 Mary Anne Warren, "On the Moral and Legal Status of Abortion," Monist 57, no. I (I973): 43-6I; Michael Tooley, Abortion and Infanticide (Oxford: Clarendon Press, 1983); Peter Singer, Practical Ethics, 2nd ed. (Cambridge: Cambridge University Press, I993); Jeff McMahan, The Ethics of Killing: Problems at the Margins of Life (New York: Oxford University Press, I992).

43 For more on this point, see Robert George, Making Men Moral (New York: Oxford University Press, I993).

44 This does not mean that all moral norms should be coercively enforced by law, or, with specific reference to the question of religion, that legal coercion in religious matters is justified. On the contrary, recognizing the true nature and importance of the good of religion shows why coercion in religious matters should be avoided. For pursuing the good of religion means seeking the truth about God and aligning oneself with that truth as one understands it. 
Perhaps Dworkin would reply that, even though laws will often incidentally promote or disfavor some comprehensive conception of the good life, there is a lack of respect for the ethical responsibility of individuals when laws do so intentionally - that is, when a primary aim of a law is paternalistic. Yet Dworkin does not think all paternalistic laws are offensive to liberty. He has no problem with things like seat belt laws or pharmaceutical regulation "because they are based on plausible assumptions about what the people's values actually are." 45 But surely not everyone prioritizes safety over freedom of movement while driving, or - to take the similar example of helmet laws-over the thrill of riding helmet-free or the desire to maintain a certain reckless, carefree image among one's companions. So such laws do impose a certain priority of values on some people and also educate people in a way that makes it likely for them to eventually make that order of priorities their own. Perhaps the real reason why Dworkin has no problem with such laws is that they clearly promote a genuine aspect of human well-being - the preservation of life and health-which practical reason, unless blinded by subrational factors, recognizes as choiceworthy. Yet religion is likewise a value that practical reason, unless blinded by subrational factors, grasps as intrinsically worthy of pursuit. Why, then, is it any more illegitimate (as a matter of principle) for laws to aim explicitly at protecting and promoting the human good of religion than the human good of life and health?

Dworkin also considers it legitimate for the community to make and legally impose decisions for the sake of protecting aesthetic values, as when zoning laws "protect the architectural or historical integrity of some part of the city," 46 even though some will inevitably disagree with those value judgments or with the prioritization of those values over others. The reason why such an imposition is justified, according to Dworkin, is that "we may leave religious and other ethical values to individual judgment and conscience, but we can only protect our aesthetic environment together." 47 Yet creating and preserving a healthy moral and religious environment requires working together at least as much as creating and preserving our aesthetic environment does, and the former is arguably more important than the latter for overall human well-being. $4^{8}$

What we find, in other words, is that Dworkin admits that the law can and should make value judgments, even sometimes paternalistic ones, and promote particular values over others for the sake of individual and collective well-being. Yet his own principles do not allow him to give a coherent explanation of why he thinks that the legal imposition or promotion of particular values is legitimate in some cases but not in others.

We see a similar problem in the approach taken by Barry. According to Barry "the essence of law is the protection of some interests at the expense of others when they come into conflict." 49 Barry cites the example of laws against rape, in which "the interests of women who do not want to be raped are given priority over the interests of potential rapists." ${ }_{5}^{\circ}$ Likewise, laws against

By its very nature as a reflexive good-a good that can only be participated in if one possesses the right inner disposition of mind and will-the good of religion cannot be achieved through coercion. And since the good of religion requires acting in line with what one sincerely (after a diligent search) believes to be the truth about God and how God wants us to act so as to be in a right relationship with him, respect for this good requires respecting the sincere religious beliefs and practices even of those whom one considers to be in some respects in error.

45 Dworkin, Is Democracy Possible Here?, 73.

46 Ibid., 7 I.

47 Ibid.

48 For more on this point, see Robert George, The Clash of Orthodoxies: Law, Religion, and Morality in Crisis (Wilmington, DE: ISI Books, 2002), chapter 5.

49 Barry, Culture and Equality, 34.

50 Ibid. 
pedophilia prioritize the interests of children over the interests of potential pedophiles. Although "these laws clearly have a much more severe impact on those who are strongly attracted to rape and paedophilia than on those who would not wish to engage in them even if there were no law against them," Barry states quite sensibly that "it is absurd to suggest that this makes the laws prohibiting them unfair." ${ }^{1}$ Similarly, claims Barry, those with expensive tastes will receive less satisfaction from their income, but this does not mean that justice requires allocating additional resources to them. ${ }^{52}$

But why? Barry himself seems to assume that we have good reason to protect the interests of those who do not want to be raped against the "interests" of potential rapists, and that there is no unfairness in the fact that those with expensive tastes will get less satisfaction from their income. His position does not, however, offer any basis for explaining why this is the case, because it is divorced from any objective claims about what human well-being consists in, and because on his view law should not aim at promoting the objective well-being of its citizens (but only leave them free to pursue their own preferences, whatever those might be).

My view, by contrast, is able to explain some of the assumptions made by Dworkin and Barry better than they themselves can. On my view, rather than being primarily about the balancing of interests or the maximal possible protection of personal choice, law is about promoting the common good, understood as the set of conditions that foster and facilitate the overall human flourishing of each of the community's members, and the pursuit of that flourishing both as individuals and as groups. 53 Thus the good of each individual is a constitutive aspect of the common good. There is, therefore, no problem at least in principle with paternalistic laws, since promoting the good of individuals is a crucial goal of law. ${ }^{54}$ With regard to Barry's examples, since freedom from sexual violation is an important condition for individual well-being, and engaging in rape is incompatible with the objective human well-being of the rapist himself, my understanding of law and of the common good explains why we have no reason to take preferences to commit rape (or other immoral acts) into account in making the law (except as prudential considerations), and also explains why laws against rape do not fail to respect the equality of the person inclined to commit rape. For on my account laws against rape protect the genuine interests (the objective human well-being) of both potential rape victims and potential rapists. Preferences to commit rape are unreasonable, and therefore the law is not unjust to those who hold those preferences when it forbids them from acting upon such preferences. 55

My account also explains why there is no lack of fairness when, due to expensive tastes, one person receives less satisfaction from his income than another. A taste for, say, caviar, is not an unreasonable preference, but it is merely a preference, and a nonrational one at that. Reason permits, but does not require the satisfaction of this preference, and the inability to do so (due to pecuniary limitations or other constraints) in and of itself involves no threat to one's objective

5 I Ibid.

52 Ibid, 35 .

53 For further discussion of the nature of the common good, see John Finnis, Natural Law and Natural Rights, especially chapter 6 .

54 On this point it is important to note that some goods (like religion) can, by their very nature, only be realized if pursued freely. Indeed, paternalistic coercion in religious matters may be not only futile but counterproductive, insofar as it may promote inauthenticity or encourage people to act against their religious convictions in order to avoid punishment. See above note 44 .

55 In many cases, of course, the common good may require that laws tolerate actions based on unreasonable preferences when prohibition of them would do more harm than good. See Thomas Aquinas, Summa Theologica, I2.96.2-3, trans. Fathers of the English Dominican Province (New York: Benziger Brothers, 1947-48). 
well-being. Thus concern for the common good (which includes the individual good of the caviarlover) does not require taking expensive tastes into account in determining the just distribution of wealth.

The same is true for preferences in general, not merely non-rational preferences like a taste for caviar. Forbidding individuals from acting in accordance even with reason-based preferences is perfectly compatible with the respect for individual well-being that the common good requires, as long as individuals have sufficient liberty to make and pursue a reasonable plan of life. Human wellbeing does not require acting upon all of one's reasonable preferences - in fact, pursuing any reasonable plan of life means prioritizing some goods over others such that many reasonable preferences have to be sacrificed. Further, human flourishing requires cooperating with others at various levels of association for the pursuit of common goods, and such cooperation requires accepting limitations on one's ability to act in accordance with reasonable preferences. Acceptance of such limitations is therefore not only compatible with individual human well-being, but is in fact required by it. There is, then, no injustice involved per se in the legal restriction of actions in accordance with reasonable preferences, because such restrictions are perfectly compatible with the well-being of those burdened by them.

This does not mean that there are no limits on the extent to which, or the manner in which, law restricts the pursuit of reasonable preferences. In order to promote the common good, the law should avoid unnecessarily restricting individual liberty with regard to the pursuit of reasonable preferences, and should also try to avoid unfairness in distributing the benefits and burdens (among which are the inevitable restrictions on individual liberty) of common life. If a law fails to meet the first requirement, it is simply unjust: it defeats its overall purpose. The second requirement, which is effectively a requirement of fairness, is more complex, since the particular burden imposed on one individual or group by one law may be offset by a particular benefit obtained from another law. Thus this fairness requirement generally applies not to any one law in isolation but to the body of law as a whole. ${ }^{6} 6$

However, laws that prevent people from doing what reason requires, or that command people to do what reason forbids, are another matter entirely. Unlike foregoing the pursuit of a reasonable preference, doing what reason forbids or failing to do what reason requires always threatens the basic human good of authenticity (harmony between one's judgments and actions). 57 Thus the burden of a law that requires one to act against a requirement (or prohibition) of reason is greater in kind, and not only in degree, than the burden of a law that limits the pursuit of reasonable preferences. Within this category of laws, laws that coerce one to act against an absolute moral prohibition present the most serious burden, insofar as positive moral obligations can sometimes be overridden in extenuating circumstances (as when one is faced with the prospect of legal punishment), ${ }^{8}$ while absolute moral prohibitions admit of no exceptions. This is true even apart from

56 This is true for laws that burden individuals with regard to the pursuit of reasonable preferences because there is no difference in kind between the sort of burden involved in restricting one type of reasonable preference satisfaction or another. Determining unfairness in this regard, therefore, requires considering the body of laws as a whole to see if one group's pursuit of reasonable preferences is significantly more burdened overall than that of other groups. When, as I argue below, what is stake are not reasonable preferences but claims regarding prohibitions or requirements of reason, the situation is different, because the burden is more serious in kind, and not only in degree, than a burden on preferences.

57 The good of inner integrity (harmony between one's feelings and judgments) is also indirectly at stake in these situations, but for the sake of simplicity I focus here only on the more directly affected good of authenticity.

58 Thus if, due to an emergency situation, all citizens are forbidden from leaving their houses on Sunday morning, in this circumstance most (perhaps all) Christians would consider themselves excused from the obligation to go to 
the good of religion, and gives reason for legislators to avoid, insofar as is possible, making laws that burden individuals' nonreligious conscientious convictions about the requirements and (especially) prohibitions of reason. ${ }^{59}$ However, when the good of religion is involved, it raises the ante even further, since what is stake is not only one's authenticity but also one's relationship with God.

For example, Burwell v. Hobby Lobby Stores, Inc. ${ }^{60}$ is clearly a case in which the law required the claimants to do something that their religion prohibited, namely, to cooperate (albeit indirectly) in the taking of embryonic human life by providing insurance coverage for certain "contraceptives" that the complainants believe may sometimes work not by preventing conception, but by preventing the early embryo from implanting in the woman's uterus. Goldman v. Weinberger, ${ }^{61}$ in which an Orthodox Jew sought an exemption from army regulations against the wearing of headgear indoors so that he could wear a yarmulke, is, conversely, a case in which the claimant is prevented from fulfilling his perceived religious obligations. ${ }^{62} \mathrm{Had}$ a standard like the one I am arguing for here, or the one established in the Religious Freedom Restoration Act (RFRA) ${ }^{63}$ and the Religious Land Use and Institutionalized Persons Act (RLUIPA), ${ }^{64}$ been applied in Goldman, I believe that he would (or should) have won the case. It is worth noting, however, that Goldman differs from Hobby Lobby in that the Hobby Lobby claimants were faced not only with a religious prohibition or requirement but also with an absolute moral prohibition, and thus their claim seems to me even weightier than Goldman's because of this additional element.

\section{HOW “RELIGIOUS” DO BELIEFS HAVE TO BE TO WARRANT SPECIAL TREATMENT IN LAW?}

It is arguably the case that any genuine appeal to objective moral obligation based on an objective order (which, on the natural law view, implies a transcendent origin) implicates the good of religion, insofar as it involves an implicit reference to something transcendent with which it is intrinsically good to be in harmony - that is, an implicit reference to the good of religion. Thus, in United States $v$. Seeger, ${ }^{65}$ involving several conscientious objectors who were not religious in the conventional sense, the justices could plausibly claim that Section 6 of the Universal Military Training and Service Act, which exempts from military service those who are conscientiously opposed to participation in war on religious grounds, does indeed apply in such cases, insofar as the overall belief system underlying the appellants' moral opposition to war held "a place in the life of its possessor parallel to that filled by the orthodox belief in God."

church. Nonetheless, it would be unjust for laws to prevent people from practicing their faith even in nonobligatory ways without a sufficient reason, given the arguments I have already made regarding the special place of religion in a flourishing human life. For more on this point, see Tollefsen, "Conscience, Religion and the State," I03.

I am thus sympathetic to Schwartzman's suggestion that nonreligious conscience claims should also receive accommodation. Nonetheless, he fails to realize that the stakes are even higher when dealing with religious claims, and thus he wrongly denies that religion warrants special protection over and above the protection granted to nonreligious conscience claims.

60 Burwell v. Hobby Lobby Stores, Inc., I34 S. Ct. 275 I (20I4).

6 I Goldman v. Weinberger, 475 U.S. 503 (1986).

62 Ibid.

6342 U.S.C. $\mathbb{S} 2000 \mathrm{bb}$ to $2000 \mathrm{bb}-4$ (I993). I discuss RFRA in greater detail below.

6442 U.S.C. $\$ 2000 c c$ et seq (2000).

65 United States v. Seeger, 380 U.S. I63 (1965). 
Exactly how "religious" one's beliefs need to be to warrant special treatment in law is a complex question. My earlier analysis of the ways in which religion is distinctive can offer a way to clarify what it means for a belief system to hold "a place in the life of its possessor parallel to that filled by the orthodox belief in God," a phrase that I believe could be adequately characterized as a test for whether or not the basic human good of religion (not merely the good of authenticity) is actually at stake, even if in an unconventional way. What $\mathrm{I}$ have argued is that religion is a distinct human good precisely because it involves a relation to the transcendent source of existence and meaning, and that this transcendent element is not only the condition sine qua non of religion's distinctiveness but is also what enables religion to have a uniquely architectonic, pervasive, and meaninggiving role in human life. As argued above, only a belief system that at least implicitly involves a relation to the transcendent, however remote and impersonal, can meet this bar. With this "transcendence criterion" in mind, and as a way of testing its limits, let us consider the beliefs of the conscientious objectors in Seeger and the companion cases decided along with it regarding Arno Jakobson and Forest Peter, as well as the more difficult later case of Welsh v. United States. ${ }^{66}$

Beginning first with the most straightforward cases, it seems clear that Arno Jakobson and Forest Peter's objections to military service did indeed meet the transcendence criterion and therefore did implicate the good of religion. According to the majority opinion in Seeger, Jakobson claimed that his "opposition to war is based on belief in a Supreme Reality, and is therefore an obligation superior to one resulting from man's relationship to his fellow man." 67 The earlier circuit court opinion in United States v. Jakobson ${ }^{68}$ describes his religious beliefs at much greater length:

He begins by defining religion as the sum and essence of one's basic attitudes to the fundamental problems of
human existence. He recognizes an ultimate cause or creator of all existence which he terms "Godness."
Jakobson sees himself as faced with an inescapable choice between acceptance or rejection of the order of
the universe; for him this is the central problem of religion. He explains the positions of acceptance and rejec-
tion by reference to the characters of Ivan and Zossima in "The Brothers Karamazov." Ivan accepts God but
rejects the world because of the evil in it; he can go on living and can love particular individuals, but can only
withdraw from the evil that he sees. Ivan doesn't oppose but passively and unhappily acquiesces; with such a
position one could go to war by disavowing any personal responsibility. Zossima represents acceptance, which
Jakobson defines as total affirmation of the basic blessedness of the fact of being-of goodness and "yesness."
The taking of human life is incompatible with acceptance, which sees in all humanity "Godness"-the quality
of having been created by the Ultimate Cause. Jakobson adopts the position of acceptance. ${ }^{69}$

Jakobson clearly believes in a transcendent cause of meaning and existence and seeks to order his life in harmony with that cause. Indeed, he explicitly recognizes the existence of an "ultimate cause" or "creator," and his objection to the taking of human life is rooted in his belief that humanity shares in "Godness" because it was "created by the Ultimate Cause." Because Jakobson's beliefs have this relation to the transcendent that I have claimed is essential to the genuine good of religion, they can also have the uniquely architectonic, pervasive, and meaning-giving characteristics of religion as well. This is, therefore, a relatively easy case of an unorthodox belief system that holds "a place in the life of its possessor parallel to that filled by the orthodox belief in God.” Like Jakobson, Forest Peter clearly claimed belief in a transcendent being, and thus his case is a relatively easy one as well. Peter stated that "his opposition to war derives from his acceptance of the existence of a

66 Welsh v. United States, 398 U.S. 333 (I970).

67 United States v. Seeger, 380 U.S. I63, I66 (I965).

68 United States v. Jakobson, 325 F.2d 409 (2nd Cir. I963).

69 Ibid. 
universal power beyond that of man, and that this acceptance, in fact, constitutes belief in a Supreme Being." 70

Daniel Seeger's beliefs, however, are less straightforward. In the majority opinion, they are described as follows:

He declared that he was conscientiously opposed to participation in war in any form by reason of his "religious" belief; that he preferred to leave the question as to his belief in a Supreme Being open, "rather than answer 'yes' or 'no"; that his "skepticism or disbelief in the existence of God" did "not necessarily mean lack of faith in anything whatsoever"; that his was a "belief in and devotion to goodness and virtue for their own sakes, and a religious faith in a purely ethical creed." R. 69-70, 73. He cited such personages as Plato, Aristotle and Spinoza for support of his ethical belief in intellectual and moral integrity "without belief in God, except in the remotest sense." 71

Seeger's statement that his disbelief in God did not imply "lack of faith in anything whatsoever," his qualification that he lacked belief in God "except in the remotest sense," and his references to Plato and Aristotle seem to indicate that he does believe in something transcendent, be it Aristotle's Prime Mover or Plato's Idea of the Good, both of which are transcendent causes in their own way. Therefore, it is reasonable to classify Seeger's beliefs as genuinely religious (as opposed to just philosophical or political) - and thus as able to play the distinctive and architectonic role in his life that orthodox religious belief does-even though he does not adhere to any particular established religion and his concept of the transcendent source of existence and meaning is unorthodox.

Welsh $v$. United States, ${ }^{72}$ which relied on Seeger as the controlling case, presents greater difficulties for my view than Seeger does, since it is more debatable whether or not Welsh's beliefs meet the transcendence criterion. On the basis of the evidence, I am confident that the beliefs of Seeger, Jakobson, and Peter can be considered "religious" according to my definition, but Welsh's beliefs are borderline at best in this regard. In fact, Welsh explicitly emphasizes that his perceived duty to abstain from killing or injuring human beings is "not 'superior to those arising from any human relation.' On the contrary: it is essential to every human relation." 73 Yet this denial could be interpreted primarily as an expression of Welsh's passionate and deeply held belief in the absolute value of human life, rather than as a denial that there is any transcendent source of that absolute value. Indeed, Judge Hamley's dissenting opinion for the earlier Ninth Circuit case provides some evidence that Welsh does believe in a transcendent source of value. Hamley calls attention, for instance, to a Hearing Officer's report "that Welsh has no belief in the existence of God or a Supreme Being, but believes in the 'natural law' as a force outside of men, such force not being an entity." 74 That Welsh's moral beliefs rest ultimately on "a force outside of men" is, on my view, an important indication that Welsh's opposition to war does have a religious element, however weak. In a 1965 letter to the Appeal Board, Welsh also wrote,

Perhaps I erred in taking such pains to point out that I not believe in the "standard notion" of God. I think my beliefs could be considered religious, in the sense I have just explained. I do not call myself religious, simply because most people then assume that I believe in God, in the conventional sense. 75

70 United States v. Seeger, 380 U.S. I66 (1965).

7I Ibid.

72 Welsh v. United States, 398 U.S. 333 (1970).

73 Ibid., 344 .

74 Welsh v. United States, 404 F.2d 1078 (9th Cir. 1969).

75 Ibid. 
In this same letter, Welsh also clarified that he had denied that his view was religious because he had thought the word was being used "in the conventional sense." Indeed, according to Hamley, "when he fully realized the broad reading which Seeger gave to that term [i.e., the term religious], Welsh made it clear that he did have a religious motivation." 76

Welsh's beliefs represent a limit case of what can count as "religious" on my definition, since the transcendent element, while arguably present, is weak and ambiguous. Even if Welsh's beliefs do not count as religious, the importance of a conscientious conviction regarding the absolute wrongness of taking human life is such that, even if this conviction had no relation to the transcendent, it should in itself be sufficient to warrant an exemption from fighting in war. On my view, Congress should have included an exemption even for nonreligious conscientious objectors out of respect for the good of authenticity. Nonetheless, the distinction made between religious and non-religious beliefs is not meaningless or lacking in a rational basis. For though ethical convictions are extremely important, religious convictions have an importance that differs in kind, and not only in degree, from ethical convictions. To be coerced to act against one's ethical convictions is a terrible thing, a threat to one's authenticity, which is a basic and constitutive aspect of human well-being. Yet to be coerced to act against one's religious convictions threatens not only one's authenticity but also one's harmony with the transcendent source of meaning and existence. There is, therefore, a distinctive, additional, and weighty burden involved when one's religious convictions are at stake that is not involved when one's convictions are merely ethical.

\section{IMPLICATIONS FOR LEGAL PROTECTION OF RELIGIOUS FREEDOM}

Having argued (I) that practical reason grasps religion as a distinct and architectonic human good, the importance of which surpasses that of nonreligious ethical and philosophical convictions; (2) that law cannot remain neutral on questions of the good, but rather that the aim of law includes the promotion of the genuine human flourishing of each member of the community as a constitutive aspect of the common good; and (3) that assessing the fairness of laws in terms of their distribution of benefits and burdens requires attentiveness to the distinctive burden involved when laws require something that reason forbids or forbid something that reason requires, I now briefly discuss the implications for religious freedom, focusing on the vexed question of whether or not there is at least a prima facie reason to grant exemptions even from neutral laws of general applicability when those laws substantially burden religious practice. As the primary aims of this article are theoretical rather than practical, I make no pretense to a complete discussion of the practical implications of my view regarding the distinctiveness of religion, or of the potential practical objections to those implications.

It follows directly from my argument in the previous section that, given the distinctive burdensomeness of laws that burden the practice of religion, granting an exemption or accommodation to those who are burdened in this way is at least a prima facie requirement of justice purely on grounds of fairness. As noted earlier, I think that there is also a special burden involved when laws require one to do something that reason forbids or forbid one from doing something that reason requires. Justice therefore also requires accommodating, where possible, nonreligious conscientious convictions of this sort, although such convictions are not on a par with religious convictions (and thus not equally deserving of accommodation) for the reasons indicated above. While in what follows I

76 Ibid. 
discuss the two cases (of religious and nonreligious convictions) together, the special importance of religious conscientious convictions should not be forgotten. Added to considerations regarding fairness is the consideration that law, since it aims at promoting human well-being, should avoid making it difficult for individuals to act in accordance with their perceived obligations, that is, to follow the dictates of conscience understood as the judgment of practical reason about what one ought to do here and now, especially when the good of religion is implicated. Law should not promote inauthenticity or prevent individuals from acting in line with their perceived religious obligations by providing strong incentives (including the threat of punishment) to act against the perceived requirements of practical reason, especially religiously informed practical reason. Further, if law should fail to make special efforts to avoid the promotion of inauthenticity or religious infidelity in this way, this would also be harmful to the common good more broadly insofar as it could be interpreted to imply that failing to be faithful to one's religious beliefs or acting against the perceived requirements of reason is not such a bad thing, resulting in a profound miseducation of the public in general with regard to these important moral truths, a miseducation that would in turn make many people more likely to be willing to act inauthentically or contrary to their religion. Some might argue that law's silence with reference to a specific aspect of human flourishing could also be a sign of respect for its unique importance, but I do not think that this can be the case when lawmakers significantly burden the pursuit of that very same good with apparent indifference.

This does not mean, of course, that if a man sincerely believes that God has commanded him to kill his daughter, offering her up in sacrifice, justice requires that he be exempted from the laws against murder. The protection of the goods of authenticity and religion involve complexities that the protection of other human goods does not, precisely because acting in accordance with the goods of authenticity and religion requires acting in accordance with one's perceived obligations, obligations that one may also understand to be grounded in the truth about God and God's requirements for human action. The judgments of practical reason are morally binding even when they happen to be in error (assuming that the error is not itself voluntary in some way). 77 As a result, there will be some situations in which following one's perceived obligations or following the will of God as one understands it involves a serious harm to the well-being of other individuals or to the community as a whole, and in these situations protection of the common good does justify forbidding someone from following even a sincerely held moral conviction or religious belief. Thus the Second Vatican Council's Declaration on Religious Freedom states that the right to religious freedom is limited by the requirements of "public order," which includes things like protection of the rights of others, the "adequate care of genuine public peace," and "the need for a proper guardianship of public morality." 78

The case of human sacrifice is an easy one. But what about a less obvious case like that dealt with in Employment Division v. Smith?79 Does justice require that members of the Native American Church, who believe that the proper worship of God requires the use of the hallucinogenic drug called peyote, be granted an exemption from an otherwise reasonable law forbidding the use of such drugs? The principles that I discussed above indicate that it does. Drug laws are not a genuine burden on others (those who do not believe what the members of the Native

77 Thomas Aquinas, Summa Theologica, I-2.9.5-6.

78 Second Vatican Council, Dignitatis Humanae [Declaration on religious freedom] (December 7, I965), $\mathbb{5}$ 7, http:// www.vatican.va/archive/hist_councils/ii_vatican_council/documents/vat-ii_decl_I965I207_dignitatis-humanae_en. html. 
American Church believe or something similar) at all, since hedonistic drug use is itself unreasonable, ${ }^{8 \circ}$ and thus the law forbids nothing that is not already forbidden by practical reason itself. On the other hand, the law is a significant burden on members of the Native American Church, who believe (as far as I understand) that the use of peyote is required for achieving harmony with God. ${ }^{8 I}$ Further, there is no evidence to indicate that the sacramental use of peyote threatens the public order any more than the sacramental use of wine in Christian liturgical celebrations threatened the public order during the era of prohibition. In terms of the educational purpose of the drug law, granting an exemption is unlikely to undermine that purpose, since the exemption is given precisely for a case in which the drug use is not for hedonistic purposes, but rather (assuming the claimants' sincerity) is for the purpose of achieving harmony with the divine. As a matter of principle, therefore, granting the members of the Native American Church the exemption that they desired does seem to be a requirement of justice.

Pace Scalia's argument in Smith, the requirement that laws be generally applicable and neutral with respect to religion is insufficient to give religious liberty the protection it deserves. ${ }^{82}$ For, as argued earlier, even if a law applies equally to all, when that law forbids a practice that religion requires (or requires a practice that religion forbids), the burden on the religious believer is greater in kind-not only in degree-than the burden on others who would prefer to act contrary to that law but have no religious reason for doing so. Thus, even neutral, generally applicable laws can seriously burden religious practice in a significantly disproportionate way, making them unjust on the grounds that they unfairly distribute the benefits and burdens of common life. Rather, the standard established by RFRA, ${ }^{83}$ which was the basis for the decision in Burwell $v$. Hobby Lobby, ${ }^{84}$ better (if imperfectly) ${ }^{85}$ corresponds to the demands of justice. RFRA forbids laws from imposing a substantial burden on religious practice unless those laws are required for the

80 See Patrick Lee and Robert George, Body-Self Dualism in Contemporary Ethics and Politics (New York: Cambridge University Press, 2008).

8 I Indeed, it might even be argued that the law's target is precisely hedonistic drug use, and thus that drug use for religious purposes (like the use of medically prescribed narcotics for pain relief) is less clearly a case of illegal activity at all.

82 To be fair, I should note here that Scalia himself might agree with this point insofar as it refers to a general requirement of justice. While Scalia denies that there is a constitutionally mandated, judicially enforceable right to exemptions, he does favor legislative exemptions.

8342 U.S.C. $\mathbb{S} \int 2000 \mathrm{bb}$ to $2000 \mathrm{bb}-4$ (1993).

84 Burwell v. Hobby Lobby Stores, Inc., I34 S. Ct. 275I (20I4). Thus the Hobby Lobby decision in no way renders the argument in this paper unnecessary, since Hobby Lobby simply presupposes and interprets RFRA, but does not address (as this would clearly be beyond the authority of the court) the underlying justice of such a law as a matter of principle.

85 I think that, in principle, RFRA should specify that there should be an even stronger presumption in favor of accommodation in cases where the law requires something that religion forbids, or forbids something that religion requires, since in these situations the burden is even greater than when the law conflicts with something that religion counsels but does not require or forbid. Perhaps this distinction could be taken into account in determining how substantial of a burden the law poses to the practice of religion. RFRA is also insufficient insofar as it only deals with "substantial" burdens on religion. In principle, there is a prima facie claim for accommodation even when the burden on religion is relatively slight. Of course, the less weighty the burden, the less serious the government interest has to be to justify imposing that burden. However, if a burden to religion can be avoided at little cost, there should be a presumption in favor of doing so. I also think that there should be a law that protects nonreligious conscientious convictions when what is at stake is either a requirement to do something that practical reason forbids or a prohibition on doing something that practical reason requires. Nonetheless, as noted with regard to the conscientious objection cases discussed above, it is reasonable and therefore not unjust to single out specifically religious convictions as deserving of unique protection and accommodation. 
achievement of a compelling state interest and are narrowly tailored to that purpose, meaning that there is no other way of achieving that interest that is less burdensome to religion. Given (I) that laws aim at the common good, which includes the good of each individual as a constitutive element, and (2) that religion plays a distinct and important role in the good life-and thus that burdens on religious practice are an especially serious threat to the well-being of individuals and communitiesit is fitting that religion be given special treatment in law that accords with its uniquely architectonic, pervasive, and meaning-giving place in a flourishing human life. Consideration of the educational function of law further supports this conclusion, because if, in the presence of laws that burden religion, no attempt at accommodation were made, this could foster a general societal attitude that fails to appreciate the true nature and importance of religion. It could foster such an attitude directly if interpreted to imply that religion does not play an essential or particularly important role in the good life, and it could also do so indirectly insofar as laws burdening religion provide incentives to religious infidelity that will shape many individuals' behavior and thus influence the culture over time.

Allow me to emphasize that the foregoing argument only establishes that the unique and basic value of religion is a prima facie reason to grant religious exemptions, not an absolute one. In some cases, especially cases of conscientious objection regarding an exceptionless duty of abstention, the reason for exemption may be specified as a conclusive right. In all cases, however, the reason is noncontingent-always supplying value to a choice made in its favor-and weighty, requiring a compelling state interest to countervail it (as established in RFRA and RLUIPA). There is, in other words, a weighty and noncontingent claim of justice to receive an exemption when a law burdens religious practice (or prevents one from following the requirements and prohibitions of conscience); the more substantial the burden, the weightier the claim. However, I have not argued (nor do I believe) that such claims (no matter how weighty) necessarily trump all other claims.

I understand that many crucial issues would need to be addressed in order to explain how the accommodationist position that I defend could be put into practice. It would be necessary, for instance, to examine the relevant issues of constitutional interpretation-such as whether the Establishment Clause forbids the government from favoring religion over nonreligion ${ }^{86}$-and to clarify the respective role of judges, legislators, and administrators in the granting of exemptions. If it does turn out to be the case that courts have a role to play in granting religious exemptions, the scope and limits of judicial authority in this regard would also have to be determined. RFRA or something like it could offer a promising approach. Of course, it would also be necessary to consider concerns (like those raised by Scalia in Smith) regarding the feasibility of a judicially

86 On this point, it should be noted that the incorporation of the Establishment Clause against the states is a matter of considerable controversy, with many scholars considering it to be logically, textually, or historically unwarranted. Frederick Mark Gedicks, "Incorporation of the Establishment Clause against the States: A Logical, Textual and Historical Analysis," Indiana Law Journal 88, no. 2 (2013): 669-722. Indeed, the First Amendment's prohibition on federal laws "respecting an establishment of religion" seems most plausibly aimed at preventing the federal government from interfering with the state religious establishments that existed at the time. Otherwise the phrase "respecting an" makes no sense, and the text could have more straightforwardly prohibited Congress from "establishing a religion." Of course, defending this controversial view is well beyond the scope of this article, and many scholars have already done so. For further discussion on this point, see the essays by Stephen D. Smith and Gerard V. Bradley in Challenges to Religious Liberty in the Twenty-First Century, ed. Gerard V. Bradley (New York: Cambridge University Press, 20I2). For a defense of incorporation of the Establishment Clause and abundant references to the literature on both sides of the debate, see Gedicks, "Incorporation of the Establishment Clause against the States." 
enforceable right of exemption. Perhaps those concerns are not as strong as scholars often assume,${ }^{87}$ or perhaps they reflect genuine difficulties that would require scaling back or even abandoning judicial enforcement of religious liberty claims. These concerns would not apply, however, to legislative accommodations to alleviate the religious burdens that arise from specific laws (such as the accommodation granted to members of the Native American Church by the Oregon legislature subsequent to Smith, allowing for the sacramental use of peyote). It would, nonetheless, still be necessary to define the limits (if any), of legislative or administrative exemptions. For instance, one would need to determine-as the justices did in Hobby Lobby - the types of corporations that could qualify for religious exemptions. My aim in this article is to defend the political philosophical claim that religious exemptions are a matter of justice; determining the practical implications of this claim for the positive law of the United States is beyond the scope of the current discussion.

\section{CONCLUSION}

I have argued here that, contrary to the views of many political and constitutional theorists, including Barry, Dworkin, Schwartzman, and Eisgruber and Sager, religion is a distinct and architectonic human good that is recognizable as such by reason, and that, given religion's special role in the well-being of both individuals and communities, it deserves special treatment in law. I have argued, further, that the standards established in RFRA and RLUIPA offer a decent, if imperfect and incomplete, model of what justice requires in this regard. Failure to give religion some such special treatment in law would not only result in unfair burdens on religious believers, but could also promote inauthenticity and religious infidelity by providing incentives to act contrary to religious beliefs, and in the long run lead to a general cultural devaluation of the goods of authenticity and religion. Further, given the presence of laws that do unfairly burden religious believers, a failure to at least make a serious effort at accommodation could send the false message that religion does not have a distinct and architectonic place in the good life, and is not important for the health of society in general. This would have seriously pernicious effects on individuals and society as a whole. Of course, much more would need to be said in order to fully establish these claims and the premises upon which they rely, but I hope at least to have shown that these are considerations that need to be taken seriously in determining the requirements of justice with respect to the protection of religious liberty and the rights of conscience more broadly, and that are insufficiently understood and appreciated in the accounts of liberal theorists.

\section{ACKNOWLEDGMENTS}

I am grateful for the feedback that I have received from many people on prior drafts of this article. Worthy of particular mention in this regard are Adam MacLeod, who offered insightful suggestions for refining several points in the penultimate draft, and the two anonymous reviewers whose fairminded, thoughtful, and detailed comments pushed me to make significant improvements to the depth and clarity of my argument.

87 For an empirical study on this point, see Michael Heise and Gregory C. Sisk, "Free Exercise of Religion before the Bench: Empirical Evidence from the Federal Courts," Notre Dame Law Review 88, no. 3 (2013): I37I-408. 